\title{
Prenatal zinc supplementation to lipopolysaccharide infected female rats prevents neurochemical, behavioral and biochemical deficits produced in infants
}

\author{
Neha Sharma, Palvi Arora, Bimla Nehru \\ Department of Biophysics, Panjab University, Chandigarh 160014, India.
}

Correspondence to: Dr. Neha Sharma, Department of Biophysics, Panjab University, Chandigarh 160014, India. E-mail: jaitly_neha@rediffmail.com

How to cite this article: Sharma N, Arora P, Nehru B. Prenatal zinc supplementation to lipopolysaccharide infected female rats prevents neurochemical, behavioral and biochemical deficits produced in infants. Neuroimmunol Neuroinflammation 2017;4:33-45.

\section{Article history: \\ Received: 29-07-2016 \\ Accepted: 13-02-2017 \\ Published: 21-03-2017}

\section{Key words:}

Neuroinflammation,

lipopolysaccharide,

motor dysfunction,

cognitive decline,

oxidative stress,

cytokines,

zinc sulphate

\section{INTRODUCTION}

\section{ABSTRACT}

Aim: Recent research revealed an association between maternal infection i.e. lipopolysaccharide (LPS) exposure during pregnancy and increased risk for central nervous system disorders being passed onto the off-spring. Therefore, the present study was designed to investigate the effect of LPS infection during d14-17 of pregnancy (equivalent to third trimester in humans) on neurochemical, neurobehavioral abnormalities, biochemical as well as histopathological parameters in male/female pups. Also, the effect of zinc supplementation throughout pregnancy to female rats in ameliorating LPS induced neurodegenerative effects caused in pups were evaluated. Methods: Pregnant female rats were administered single dose of LPS $(200 \mu \mathrm{g} / \mathrm{kg})$ intraperitoneal on d14-17 of their pregnancy. Zinc supplementation was given throughout pregnancy $\left(75 \mathrm{mg} \mathrm{ZnSO}_{4} / \mathrm{L}\right)$ in drinking water. Results: LPS injection to pregnant female rats significantly altered the levels of neurotransmitters (dopamine, serotonin and norepinephrine) in pups. Also, marked deterioration of motor behavior parameters (actophotometer, rotarod) as well as cognitive decline (plus maze and active avoidance) has been observed in male as well as female pups. Whereas, supplementation with zinc limited the alterations in behavioral parameters as well as significantly improved the level of neurotransmitters in prenatally exposed pups of both genders. However, levels of malondialdehyde and nitric oxide formed as well as antioxidant defense system including reduced glutathione, superoxide dismutase and catalase were found to be excessively compromised in female pups when compared to male pups. Conclusion: Hence, the study indicated LPS mediated toxicity in prenatally exposed pups is gender specific and zinc supplementation during pregnancy was found to attenuate LPS induced toxicity in pups.

walls in gram-negative bacteria and is widely present in the digestive tract of humans and animals. ${ }^{[1]}$ As revealed by recent studies humans often get exposed to LPS

Lipopolysaccharide (LPS) is a toxic component of cell 
as it is present suspended in the air as a component of the air pollutant PM2.5 or as part of house dust and aerosols generated from contaminated water. ${ }^{[2,3]}$ These PM2.5 i.e. particulate matter less than $2.5 \mu \mathrm{m}$ originate from several sources like oil refineries, metal processing facilities, tailpipe and brake emissions, residential fuel combustion, power plants, and wild fires. Furthermore, occupational exposure to LPS is common for people in agricultural settings or in textile mills as suggested by previous reports..$^{[4]}$ It has also been reported that gastrointestinal distress and excess alcohol intake are known to increase uptake of LPS from gastrointestinal tract into blood. ${ }^{[5,6]}$

Further, high levels of LPS have also been detected in women with bacterial vaginosis. ${ }^{[7]}$ In humans, gramnegative bacterial infections are a recognized cause of embryo loss and preterm labor. ${ }^{[8]}$ Mimicking maternal infection by exposing the pregnant rodents to LPS at early gestational stages resulted in embryonic resorption and fetal death. ${ }^{[9,10]}$ LPS exposure at middle gestational stages caused teratogenesis, fetal death and preterm delivery. ${ }^{[11-13]}$ In addition, several studies showed that maternal LPS exposure at late gestational stages led to fetal death, growth restriction, skeletal development retardation, and preterm labor. ${ }^{[14-18]}$

Numerous reports demonstrate that inflammatory cytokines, such as tumor necrosis factor alpha (TNF- $\alpha$ ), have been associated with LPS-induced adverse developmental outcomes. Indeed, several studies showed that maternal LPS exposure during pregnancy significantly increased the level of proinflammatory cytokines in maternal serum, amniotic fluid, fetal liver, and fetal brain. ${ }^{[19,20]}$ Another study found that the expression of TNF- $\alpha, I L-1 \beta$ and IL- 6 is also much higher in brains with periventricular leukomalacia (PVL) than in those without PVL. ${ }^{[1]}$ Mimicking intrauterine infection and inflammation by LPS exposure during pregnancy significantly increased the levels of TNF- $\alpha$, interleukin-1 $\beta$ (IL-1 $\beta$ ) and IL-6 in maternal serum, fetal liver and amniotic fluid, TNF- $\alpha$ and IL-10 in fetal brain in rodents. ${ }^{[18]}$ Several studies showed that maternal exposure of LPS $(120 \mu \mathrm{g} / \mathrm{kg})$ intraperitoneal in mouse at late gestational stages markedly impaired the learning abilities and social behavioral performance in adulthood. ${ }^{[22-24]}$

Nutritional deficits may also cause neurodevelopmental disorders, such as spina bifida, which is common, and anencephaly, which is rare. Both disorders are neural tube defects with malformation and dysfunction of the nervous system and its supporting structures, leading to serious physical disability. Folic acid (vitamin B) supplementation in early pregnancy, aimed to prevent neural tube defects, may also reduce mental health problems in children. ${ }^{[25]}$ Iodine deficiency in the pregnant mother subsequently causes hypothyroxinemia i.e. low maternal free thyroxine $\left(T_{4}\right)$ and results in damage to the developing brain, which is further aggravated by cretinism in the fetus.

Zinc is also one of an essential element in diet of pregnant females as maternal zinc deficiency affects fetal growth and development, complications of pregnancy, labor and delivery and maternal and infant health. ${ }^{[2]]}$ Zinc is a structural constituent essential for cell growth, development, and differentiation. ${ }^{[27]}$ Increasing evidence demonstrates that zinc has an anti-inflammatory effect. ${ }^{[28]} A$ recent study found that subcutaneous injection with zinc sulfate alleviated LPSinduced neurodevelopmental damage in fetal brain. ${ }^{[29,30]}$ Zinc is capable of inhibiting LPS or IL-1 $\beta$-induced nitric oxide (NO) formation as well as NO formation by $\mathrm{NO}$ synthase (NOS). ${ }^{[31]}$ Many studies reported that $\mathrm{Zn}^{2+}$ inhibits LPS-induced TNF- $\alpha$ production by inactivating nuclear factor- $\kappa \mathrm{B}(\mathrm{NF}-\kappa \mathrm{B})$ genes which is mediated by

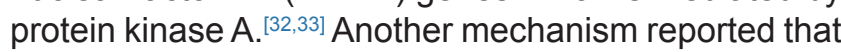
$\mathrm{Zn}^{2+}$ increased the intracellular levels of cGMP due to reduced enzyme activity of phosphodiestrase-1 (PDE-1), PDE-3, PDE-4 in cellular lysate and inhibits the LPS-induced TNF- $\alpha$ and IL-1 $\beta .{ }^{[34]}$ The development of anxiety has been previously reported in zinc-deficient rats. ${ }^{[35,36]}$ Zinc can act as a critical neural messenger in healthy and diseased states of the brain through its ability to regulate $\mathrm{N}$-methyl-D-aspartate receptor activity which have central importance in cognitive functions (learning and memory). ${ }^{[3]}$ Recent studies showed that $\mathrm{ZnSO}_{4}$ supplementation during pregnancy protects against LPS-induced fetal growth restriction and demise through its anti-inflammatory effect. ${ }^{[28]}$

Nevertheless, the molecular mechanism of zinc-mediated protection against LPS induced developmental toxicity remains elusive. Present study was designed to investigate the gender biased effects of LPS injection during d14-17 of pregnancy on the neurobehavioral, biochemical and histopathological parameters in off-springs. Also, the neuroprotective potentials of zinc supplementation in ameliorating these LPS induced alterations have been established.

\section{METHODS}

\section{Animals}

Healthy Sprague-Dawley rats between 5-7 weeks age were procured at the central animal house of Panjab University, Chandigarh, India. They were acclimatized in the department animal house for two weeks in polypropylene cages in hygienic conditions. They were 
provided standard animal feed and water ad libitum throughout the treatment period. All procedures were done in accordance with ethical guidelines laid down by the Ethics Committee on the Use of Experimental Animals of the Panjab University and in general according to the $\mathrm{NIH}$ guidelines (Rule No. 23-85, as revised in 1985).

\section{Chemicals}

All the chemicals were purchased from Sigma-Aldrich (St. Louis, USA) and Sisco Research laboratories Pvt., Ltd. (Mumbai, India). Zinc sulfate was purchased from HiMedia (Mumbai, India).

\section{Experimental design}

Rats were preferred for this experiment due to: (1) shorter gestation length (20-22 days), shorter estrous cycle (4-5 days), litter size of about 7-9, weaning age of about 21 days and relatively short period age of sexual maturity (7-8 weeks). Rat pregnancies are more size consistent, rats can bred quickly after parturition and rat brains show early sexual dimorphism. ${ }^{[38]}$ At the commencement of the study 12 female rats of 12-14 weeks of age were randomly distributed into four cages with 1 male of $14-16$ weeks of age into each cage. ${ }^{[38]}$ Pregnant female rats were then divided into four cages and were grouped as follows:

Group A (control): pregnant females were injected intraperitoneal with single dose of normal saline $(200 \mu \mathrm{L})$ at day 14 of pregnancy; Group B (LPS treated): pregnant females were injected with single dose of LPS $(200 \mu \mathrm{g} / \mathrm{kg})$ intraperitoneal at day 14 of pregnancy; Group C (LPS + zinc supplemented): pregnant females were injected single dose of LPS $(200 \mu \mathrm{g} / \mathrm{kg})$ intraperitoneal at day 14 of pregnancy. Animals were also administered with $\mathrm{ZnSO}_{4}(75 \mathrm{mg} / \mathrm{L})$ dissolved in drinking water throughout their gestation period; Group D (zinc supplemented): pregnant females were supplemented with $\mathrm{ZnSO}_{4}(75 \mathrm{mg} / \mathrm{L})$ throughout their gestation period.

\section{Neurobehavioral analysis}

Elevated plus maze test

Elevated plus maze (EPM) test is a learning task which measures spatial long-term memory and evaluates the cognitive behavior. ${ }^{[39]}$ Apparatus used for the EPM test consists of 2 open arms $(40 \mathrm{~cm} \times 6 \mathrm{~cm})$ and 2 closed arms of the same size connected with a central platform $(6 \mathrm{~cm} \times 6 \mathrm{~cm})$. The maze was placed $50 \mathrm{~cm}$ above the ground. Rats were allowed to move freely in this apparatus for $90 \mathrm{~min}$ of training. After a few hours, trained pups were again allowed to move freely for the same time and time spent in the open arms and closed arms were analyzed. The apparatus was cleaned with $25 \%$ ethanol after testing the pups.

\section{Active avoidance test}

Memory impairments can be observed in Active Avoidance Test. ${ }^{[40]}$ Apparatus used for this test consisted of 2 chambers, which are separated by a partition. One of these chambers is enlightened, where the animal has to be kept. After $10 \mathrm{~s}$, the buzzer is kept on and after $10 \mathrm{~s}$ the shock is given. If the animal jumps to the other side of the compartment as soon as the buzzer is set on, it means the animal has avoided the test. But in case, if the animal jumps to the other compartment aftershock or does not jump is termed as escapism. The number of escaped trials/2 min/animal were noted and analyzed statistically.

\section{Actophotometer (total locomotor activity)}

Total locomotor activity (ambulation's and rearing) was measured by using a computerized Actophotometer (IMCORP, Ambala, India). An array of 16 infrared emitter/detector pairs measured animal activity along a single axis of motion, the digital data being displayed on the front panel meters as ambulatory movements. Rats were allowed to acclimatize to the observation chamber for a period of $2 \mathrm{~min}$. The activity was monitored continuously for a period of $5 \mathrm{~min}$. Locomotion was expressed in terms of total photo beam counts per 5 min period per animal. ${ }^{[4]]}$

\section{Rotarod}

The effect of LPS on the muscle performance was evaluated using a Rota-rod. Animals were given 2 initial training trails of $300 \mathrm{~s}$ each, approximately $10 \mathrm{~min}$ apart, to maintain posture on a Rota-rod which is $3 \mathrm{~cm}$ in diameter and rotating at a constant 25 revolution per minute. After the initial training trials, a baseline trial of $120 \mathrm{~s}$ was conducted. The time each animal remained on the rotarod was recorded; animals not falling off the rotarod were given a maximum score of $120 \mathrm{~s} .{ }^{[42]}$

\section{Estimation of neurotransmitter levels (epinephrine, nor-epinephrine, dopamine and serotonin)}

Biogenic amines dopamine, norepinephrine and serotonin were measured by high performance liquid chromatography (HPLC) with electrochemical detector ${ }^{[43]}$ Water standard system consisting of a high pressure isocratic pump. A $20 \mu \mathrm{L}$ sample injector valve, C18 reverse phase column and electrochemical device were used. Data was recorded and analyzed with the help of Empower software. Mobile phase consisting of $10 \mathrm{mmol} / \mathrm{L}$ sodium citrate, $32 \mathrm{mmol} / \mathrm{L}$ $\mathrm{NaH}_{2} \mathrm{PO}_{4}, 0.025 \mathrm{mmol} / \mathrm{L}$ EDTA, and $0.77 \mathrm{mmol} / \mathrm{L}$ 1-heptane sulphonic acid was used. pH of mobile phase was adjusted to 4.5 with the help of orthophosphoric acid. Electrochemical conditions for the experiment were $+0.800 \mathrm{~V}$, sensitivity ranges from 5-50 $\mathrm{nA}$. 
Separation was carried out at a flow of $1 \mathrm{~mL} / \mathrm{min}$. Samples $(20 \mu \mathrm{L})$ were injected manually. On the day of experiment frozen samples of midbrain were homogenized in the homogenizing solution containing $0.1 \mathrm{~mol} / \mathrm{L}$ perchloric acid. After that samples were centrifuged at $12,000 \mathrm{~g}$ for $5 \mathrm{~min}$. The supernatant was further filtered through 0.25 micron nylon filters before injecting in the HPLC injection pump. Data was recorded and analyzed with the help of Empower software. ${ }^{[43]}$

\section{Biochemical estimations}

All the tissues $(10 \% \mathrm{w} / \mathrm{v})$ were homogenized in $10 \mathrm{mmol} / \mathrm{L}$ PBS, $\mathrm{pH}=7.4$. Homogenate was made using mechanically driven Teflon Potter-Elvejhem type homogenizer for total disruption of cells. Homogenate was centrifuged first at $10,000 \mathrm{~g}$ for $30 \mathrm{~min}$ at $40{ }^{\circ} \mathrm{C}$. Pellet was discarded and supernatant was used for various biochemical estimations.

\section{NO}

NO was estimated by the method of Raddassi et al. ${ }^{[44]}$ The level of NO was estimated as nitrite, a NO metabolite and remains stored in tissues as Nitrates $\left(\mathrm{NO}^{3-}\right)$ or Nitrite $\left(\mathrm{NO}^{2-}\right)$. Thus, $\mathrm{NO}$ concentration can be estimated by measuring concentrations of $\mathrm{NO}^{3-}$ and $\mathrm{NO}^{2-}$ in combination. The simplest technique is the monitoring of reduction of $\mathrm{NO}^{3-}$ to $\mathrm{NO}^{2-}$ by nitrate reductase or metallic catalyst, followed by the calorimetric Griess Reaction to measure $\mathrm{NO}^{2-}$ levels (nitrite levels). A standard curve was made with serial dilutions of sodium nitrite by making its volume to $100 \mu \mathrm{L}$; add $100 \mu \mathrm{L}$ of Griess reagent in wells of ELISA reader plate. Instead of sodium nitrite $100 \mu \mathrm{L}$ of homogenate was added along with $100 \mu \mathrm{L}$ of Griess reagent in subsequent wells of ELISA plate. The colorimetric reaction was allowed to proceed for $10 \mathrm{~min}$ at room temperature in dark, and optical density was measured at $550 \mathrm{~nm}$ using ELISA reader.

\section{Glutathione reduced}

Estimation of glutathione reduced (GSH) was performed in the tissue homogenate by the method of Moron et al. ${ }^{[34]}$ The assay was performed by mixing $100 \mu \mathrm{L}$ of $2.5 \%$ homogenate and trichloroacetic acid (TCA). The precipitated proteins were separated by centrifugation at $2,000 \mathrm{~g}$ for $15 \mathrm{~min} ; 0.1 \mathrm{~mL}$ supernatant was diluted to $1 \mathrm{~mL}$ with $0.2 \mathrm{~mol} / \mathrm{L}$ phosphate buffer $(\mathrm{pH}$ $=8.0$ ). Further, $2 \mathrm{~mL}$ of freshly prepared $0.6 \mathrm{mmol} / \mathrm{L}$ 5,5'-dithiobis (2-nitrobenzoic acid) (DTNB) in buffer was added. In this method, DTNB is reduced by $-\mathrm{SH}$ groups to form 1 mole of 2-nitro-5-mercaptabenzoic acid per mole of $\mathrm{SH}$. The nitro mercaptobenzoic acid anion released has intense yellow color and can be used to measure $-\mathrm{SH}$ groups at $412 \mathrm{~nm}$.

\section{Lipid peroxidation (MDA) assay}

Lipid peroxide formation was assayed by the method of Wills. ${ }^{[45]}$ An aliquot containing $0.5 \mathrm{~mL}$ of tissue homogenate $(10 \% \mathrm{w} / \mathrm{v})$, diluted to $1.0 \mathrm{~mL}$ using $0.1 \mathrm{~mL}$ Tris- $\mathrm{HCl}$ buffer $(\mathrm{pH}=7.4)$ was shaken. Samples were incubated at $37{ }^{\circ} \mathrm{C}$ for $2 \mathrm{~h}$ with constant shaking. After incubation, $1 \mathrm{~mL}$ of ice cold $10 \%$ TCA was added and mixed it thoroughly; the reaction mixture was centrifuged at $800 \mathrm{~g}$ for $10 \mathrm{~min}$. One $\mathrm{mL}$ of $0.67 \%$ thiobarbituric acid (TBA) was added to $1 \mathrm{~mL}$ of supernatant and color developed at $100{ }^{\circ} \mathrm{C}$ for $10 \mathrm{~min}$. Samples were cooled and diluted with $1 \mathrm{~mL}$ double distilled water. The absorbance was read at $532 \mathrm{~nm}$. The amount of Malondialdehyde formed was calculated on the basis of molar extinction coefficient of MDA-TBA chromophore $\left(1.56 \times 10^{5} \mathrm{M}^{-1} \mathrm{~cm}^{-1}\right)$ and results were expressed as nmoles of MDA/mg protein.

\section{Catalase}

The enzymatic activity of catalase was estimated by UV spectrophotometer method described by Luck. ${ }^{[46]} \mathrm{H}_{2} \mathrm{O}_{2}$ was used as substrate. The UV absorption of $\mathrm{H}_{2} \mathrm{O}_{2}$ solution is measured at $240 \mathrm{~nm}$ on decomposition of $\mathrm{H}_{2} \mathrm{O}_{2}$ with catalase. The amount of $\mathrm{H}_{2} \mathrm{O}_{2}$ decomposed was calculated on the basis of molar extinction coefficient of $\mathrm{H}_{2} \mathrm{O}_{2}\left(39.4 \mathrm{M}^{-1} \mathrm{~cm}^{-1}\right)$ and results were expressed as $\mu$ moles of $\mathrm{H}_{2} \mathrm{O}_{2}$ decomposed $/ \mathrm{min} / \mathrm{mg}$ protein.

\section{Superoxide dismutase}

Superoxide dismutase (SOD) estimation was assayed by the method of Kono. ${ }^{[47]}$ The principle of SOD activity assay was based on the inhibition of nitrobluetetrazolium (NBT) reduction using the following reagents. Solution A: EDTA $(0.1 \mathrm{mmol} / \mathrm{L})$ containing $50 \mathrm{mmol} / \mathrm{L}$ sodium carbonate, $\mathrm{pH} 10.0$; solution B: NBT $(90 \mathrm{mmol} / \mathrm{L})$ in solution A; solution C: Triton-X $(0.6 \%)$ in solution $A$; solution D: hydroxylamine hydrochloride $(20 \mathrm{mmol} / \mathrm{L})$ $\mathrm{pH}$ 6.0. The reaction mixture contained $1.3 \mathrm{~mL}$ of solution $\mathrm{A}, 0.5 \mathrm{~mL}$ of solution $B$ and $0.1 \mathrm{~mL}$ of solution C. The reaction is initiated by the addition of $0.1 \mathrm{~mL}$ of solution $D$ to the reaction mixture and the rate of reduction of NBT in the absence of enzyme source was recorded at $560 \mathrm{~nm}$ for $3 \mathrm{~min}$, which is considered as reference. Following this an appropriate amount of the enzyme source (PMS 20-50 $\mu \mathrm{L}$ ) was added and the rate of reduction was noted for $3 \mathrm{~min}$ at $560 \mathrm{~nm}$. Percentage inhibition in the rate of NBT reduction is calculated and one unit of the enzyme that is the inverse of the amount of the protein $(\mathrm{mg})$ required to inhibiting the reduction rate by $50 \%$. The results are expressed as IU/mg of protein.

\section{Histopathology}

Histology of brain tissues was done by the method 
of Humanson. ${ }^{[48]}$ All brain tissue sections were fixed in $10 \%$ neutral buffered formalin. The tissues were processed and embedded in paraffin and sectioned at $4 \mu \mathrm{m}$ thickness. The sections were stained with hematoxylin and eosin (HE). The dried stained slides were seen under the Leica microscope. Images were captured at $10 \times$ and $40 \times$ and auto corrected in Microsoft office 2010 to enhance image clarity.

\section{Statistical analysis}

Statistical analysis was done by one way ANOVA followed by LSD with post-hoc multiple pairwise comparisons between genders and different groups to estimate whether the differences between the mean values of groups are statistically significant or not. Results were taken significant at $P \leq 0.05$.

\section{RESULTS}

Prenatal zinc supplementation improves LPS induced neurobehavioral deficits in pups

Total locomotor activity was assessed in prenatally LPS treated male and female pups on actophotometer. Prenatal LPS exposure significantly $(P<0.05)$ decreased total locomotor activity in male $(31.59 \%)$ as well as female (30.17\%) pups when compared to control pups. Zinc supplememtaion to female rats throughout pregnancy improved locomotor activity in case of female pups (21.60\%) [Figure 1]. In case of rotarod test a significantly $(P<0.05)$ decreased mean fall off time was observed in $(54.30 \%)$ male and $(65.93 \%)$ female pups in comparison to control pups. Zinc supplementation however significanty increased the mean fall off time in pups of both sexes.

Spatial memory was assessed in prenatally LPS treated male and female pups using a EPM as well as active avoidance test as shown in Figure 2. Time spent in closed arm was significantly $(P<0.05)$ decreased in case of prenatally LPS treated male pups $(66.23 \%)$ and female pups (6-fold) when compared to control pups. However, following zinc supplementation time spent in the closed arm was significantly $(P<0.05)$ increased in male $(14.84 \%)$ and female $(47.26 \%)$ pups when compared to LPS treated pups.
Prenatally LPS exposed pups of both genders showed significant $(P<0.05)$ increase $(2$-fold $)$ in the number of escaped trials when compared to control pups. However, number of escaped trials were significantly $(P<0.05)$ decreased in male $(35.29 \%)$ and female (41.67\%) pups following zinc supplementation to LPS treated mothers when compared to prenatally LPS treated pups.

Effect of prenatal zinc supplementation on neurotransmitter levels in pups

Present study relates the deficit in locomotor activity and short term memory with neurotransmitter levels which were measured using HPLC as shown in Table 1. Prenatal LPS exposure significantly $(P<0.05)$ decreased the level of dopamine in male $(38.37 \%)$ and female $(41.70 \%)$ pups when compared to control pups. In case of pups from zinc supplemented mothers a significant $(P<0.05)$ improvement in dopamine level was observed (male 52.2\%) and (female 13.37\%) when compared to prenatally LPS treated pups.

Prenatal LPS exposure significantly $(P<0.05)$ increased the level of norepinephrine (NE) in male $(78.21 \%)$ and female (24.42\%) pups when compared to control pups. However, NE levels were found to decrease significantly $(P<0.05)$ in male $(27.98 \%)$ as well as female pups $(14.42 \%)$ following zinc supplementation to LPS treated mothers when compared to prenatally LPS treated pups.

Prenatal LPS exposure also significantly $(P<0.05)$ decreased the level of $5-\mathrm{HT}$ in male $(30.58 \%)$ and female $(55.76 \%)$ pups when compared to control pups. Whereas, 5-HT levels were significantly $(P<0.05)$ improved with $(14.40 \%)$ increase in male and female $(60.86 \%)$ pups following zinc supplementation to LPS treated mothers when compared to prenatally LPS treated pups.

Effect of prenatal zinc supplementation on oxidative stress markers (NO levels, MDA level (lipid peroxidation) and antioxidant enzymes (GSH, SOD and catalase)

As seen from Table 2 a significant $(P<0.05)$ elevation

Table 1: Effect of prenatal zinc supplementation on neurotransmitter levels in mid brain of prenatally LPS treated male and female pups

\begin{tabular}{lllllll}
\hline \multirow{2}{*}{ Group } & \multicolumn{2}{c}{ Dopamine $(\mathrm{ng} / \mathrm{mg}$ tissue) } & \multicolumn{2}{c}{ Serotonin (ng/mg tissue) } & \multicolumn{2}{c}{ Norepinephrine } \\
\cline { 2 - 7 } & Male & Female & Male & Female & Male & Female \\
\hline Control & $0.645 \pm 0.050$ & $0.885 \pm 0.040$ & $0.340 \pm 0.030$ & $0.260 \pm 0.007$ & $3.81 \pm 0.08$ & $5.69 \pm 0.13$ \\
LPS & $0.398 \pm 0.030^{*}$ & $0.516 \pm 0.060^{*}$ & $0.236 \pm 0.000^{*}$ & $0.115 \pm 0.005^{*}$ & $6.79 \pm 0.08^{*}$ & $7.07 \pm 0.12^{*}$ \\
$\mathrm{LPS}_{+} \mathrm{ZnSO}_{4}$ & $0.605 \pm 0.050^{*}$ & $0.585 \pm 0.030^{\#}$ & $0.270 \pm 0.010^{\#}$ & $0.185 \pm 0.005^{\#}$ & $4.89 \pm 0.08^{*}$ & $6.05 \pm 0.11^{\#}$ \\
$\mathrm{ZnSO}_{4}$ & $0.748 \pm 0.020^{* \#}$ & $0.901 \pm 0.010^{\#}$ & $0.313 \pm 0.010^{* \#}$ & $0.245 \pm 0.005^{\#}$ & $3.08 \pm 0.08^{*}$ & $5.05 \pm 0.11^{*}$ \\
\hline
\end{tabular}

Values are expressed as mean $+\mathrm{SD} ; n=5$ /group. ${ }^{*} P<0.05$ vs. control group, ${ }^{\sharp} P<0.05$ vs. prenatally LPS treated group. LPS: lipopolysaccharide 
Table 2: Effect of prenatal zinc supplementation on NO levels, lipid peroxidation and antioxidant defense system in mid brain of prenatally LPS treated male and female pups

\begin{tabular}{|c|c|c|c|c|c|}
\hline Group & $\begin{array}{l}\text { NO (nmoles/mg } \\
\text { protein) }\end{array}$ & $\begin{array}{l}\text { LPO (nmoles of } \\
\text { MDA/mg protein) }\end{array}$ & $\begin{array}{l}\text { GSH ( } \mu \text { moles/ } \\
\text { mg protein) }\end{array}$ & SOD (I.U) & $\begin{array}{l}\text { Catalase (nmoles of } \\
\mathrm{H}_{2} \mathrm{O}_{2} \text { hydrolysed/mg } \\
\text { protein/min }\end{array}$ \\
\hline \multicolumn{6}{|l|}{ Male } \\
\hline Control & $0.389 \pm 0.051$ & $40.11 \pm 7.64$ & $31.91 \pm 0.60$ & $0.349 \pm 0.054$ & $0.700 \pm 0.120$ \\
\hline LPS & $0.430 \pm 0.020$ & $50.03 \pm 5.54$ & $12.26 \pm 1.09$ & $0.269 \pm 0.041$ & $0.540 \pm 0.062$ \\
\hline $\mathrm{LPS}+\mathrm{ZnSO}_{4}$ & $0.314 \pm 0.038^{\#}$ & $45.41 \pm 7.60^{\#}$ & $19.69 \pm 1.68^{\#}$ & $0.290 \pm 0.035$ & $0.610 \pm 0.082$ \\
\hline $\mathrm{ZnSO}_{4}$ & $0.357 \pm 0.054^{\#}$ & $36.50 \pm 9.76$ & $31.25 \pm 1.34^{\#}$ & $0.340 \pm 0.033$ & $0.800 \pm 0.091^{\#}$ \\
\hline \multicolumn{6}{|l|}{ Female } \\
\hline Control & $0.299 \pm 0.028$ & $39.95 \pm 7.57$ & $29.77 \pm 1.04$ & $0.607 \pm 0.013$ & $1.000+0.170$ \\
\hline LPS & $0.438 \pm 0.022$ & $55.13 \pm 4.79$ & $12.01 \pm 0.70$ & $0.407 \pm 0.050^{\circ}$ & $0.670+0.083^{*}$ \\
\hline $\mathrm{LPS}+\mathrm{ZnSO}_{4}$ & $0.321 \pm 0.066^{\#}$ & $41.14 \pm 6.50^{\#}$ & $20.84 \pm 0.68^{\#}$ & $0.470 \pm 0.050$ & $0.750+0.110$ \\
\hline $\mathrm{ZnSO}_{4}$ & $0.299 \pm 0.038^{\#}$ & $27.36 \pm 4.29^{\#}$ & $29.37 \pm 0.90^{\#}$ & $0.716 \pm 0.110^{* \#}$ & $1.160+0.180^{\#}$ \\
\hline
\end{tabular}

Values are expressed as mean $+\mathrm{SD} ; n=5 /$ group. ${ }^{*} P<0.05$ vs. control group, ${ }^{\#} P<0.05$ vs. prenatally LPS treated group. LPS: lipopolysaccharide; NO: nitric oxide; LPO: lipid peroxidation; GSH: reduced glutathione; SOD: superoxide dismutase
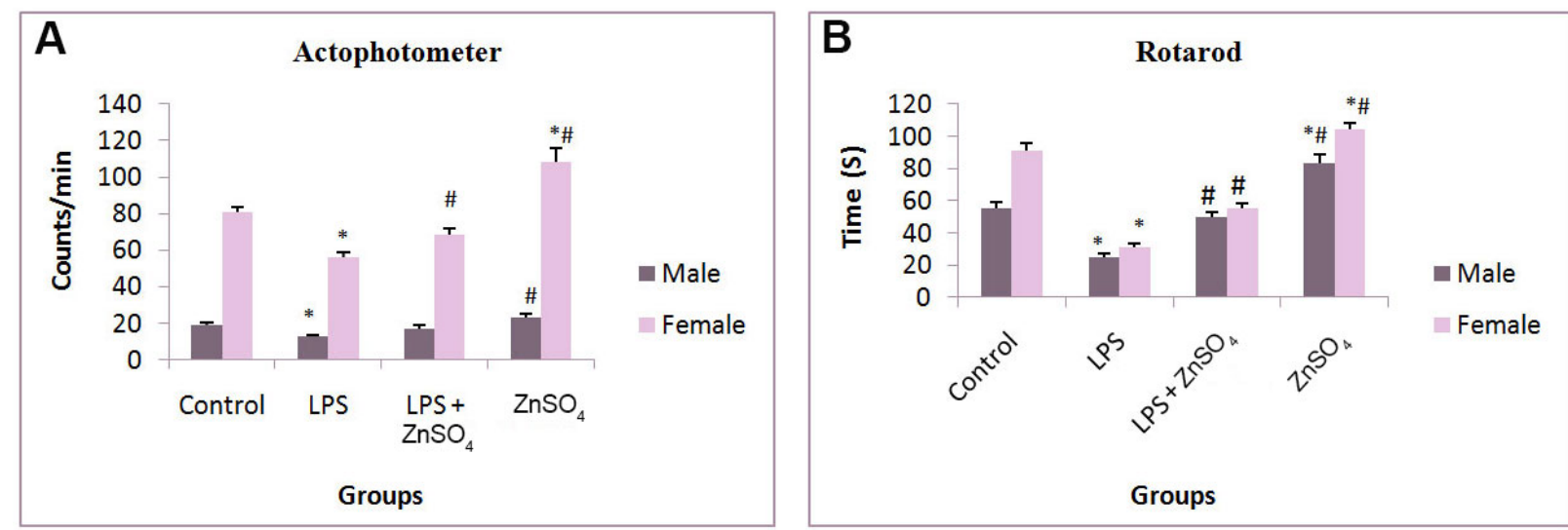

Figure 1: Effect of prenatal zinc supplementation in (A) actophotometer and (B) rotarod on prenatally LPS treated male pups and female pups. Values are expressed as mean $+\mathrm{SD} ; n=5$ /group, ${ }^{\star} P<0.05$ vs. control group, ${ }^{\#} P<0.05$ vs. prenatally LPS treated group. LPS: lipopolysaccharide

in NO levels were observed only in prenatally LPS treated female pups $(46.49 \%)$ when compared to control pups. However, with zinc supplementation to LPS treated pregnant rats significantly $(P<0.05)$ decreased NO levels in female $(26.71 \%)$ pups when compared to prenatally LPS treated pups. Prenatally LPS exposed female pups showed significant $(P<$ $0.05)$ increase in lipid peroxidation when compared to control pups (37.99\%). However, significant ( $P$ $<0.05)$ decrease in MDA levels were observed in case of female pups from zinc supplemented mothers $(25.37 \%)$. Similarly, prenatal LPS exposure significantly $(P<0.05)$ decreased the GSH levels in male $(61.57 \%)$ and female $(59.65 \%)$ pups when compared to control pups. However, GSH levels were found to be significantly $(P<0.05)$ increased in male $(60.60 \%)$ and female $(73.52 \%)$ pups following zinc supplementation to their LPS treated mothers when compared to prenatally LPS treated pups. Prenatal LPS exposure significantly $(P<0.05)$ decreased the enzymatic activity of Catalase (33\%) and SOD $(32.94 \%)$ in only female pups when compared to control pups. Whereas, pups following zinc supplementation to their
LPS treated mothers showed non-significant results when compared to prenatally LPS treated pups.

\section{Histopathological studies}

Coronal section from both male and female pups from prenatally exposed female rats were prepared to analyse LPS induced alterations in hippocmapus and cortex region. Figure 3 shows the histoarchitecture of hippocampus and Figure 4 cortex of all the groups for both prenatally LPS exposed (A) male and $(B)$ female pups respectively. Necrotic cells with inflammatory infilterate were seen in histological slides of hippocampus and cortex area in prenatally LPS exposed both male and female pups. Cystic lesions were also observed in the cortex of prenatally LPS exposed male pups. Decrease in the number of necrotic cells was observed in hippocampus as well as cotex of zinc supplemented group for both male and female pups.

\section{DISCUSSION}

In the current study, the effects of prenatal zinc 

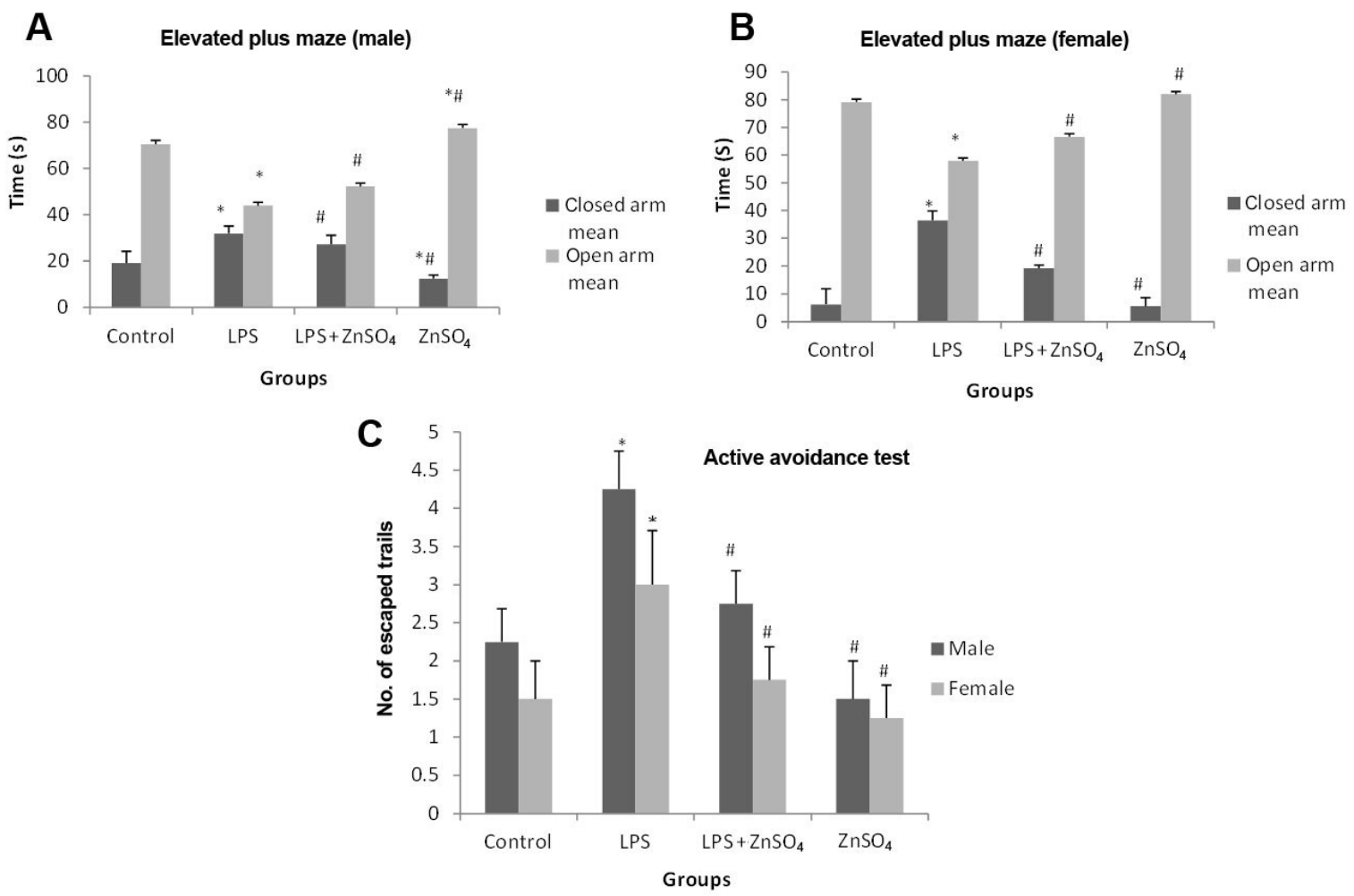

Figure 2: Effect of prenatal zinc supplementation on elevated plus maze in prenatally LPS treated (A) male pups, (B) female pups and in (C) active avoidance test on both the genders. Values are expressed as mean $+\mathrm{SD} ; n=5 /$ group, ${ }^{*} P<0.05$ vs. control group, ${ }^{\#} P<0.05$ vs. prenatally LPS treated group. LPS: lipopolysaccharide

A

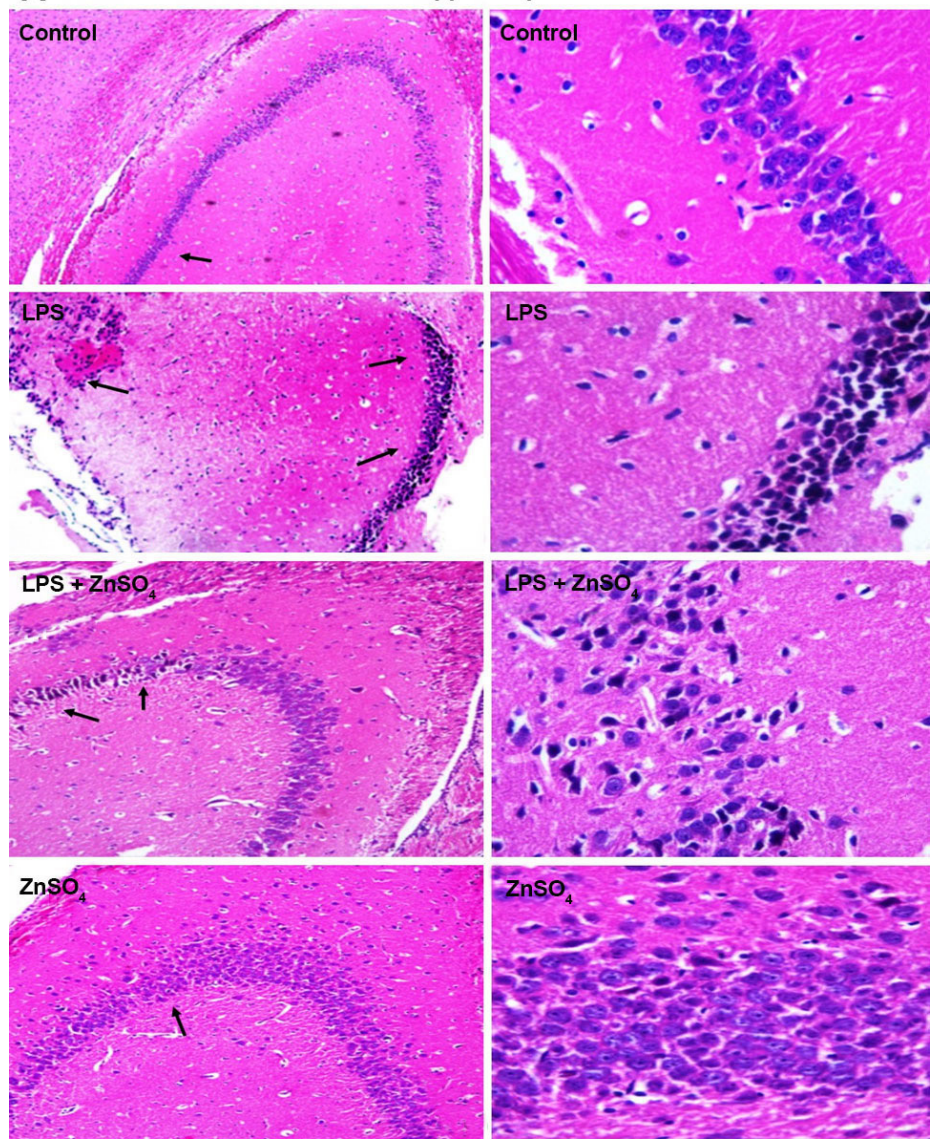


B
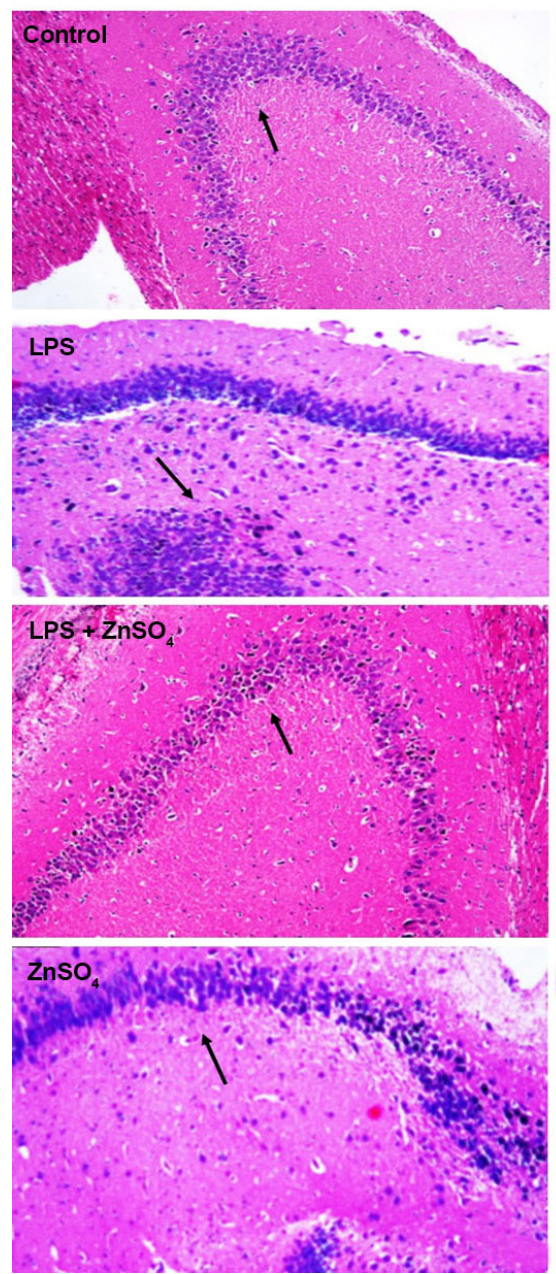

Hippocampus
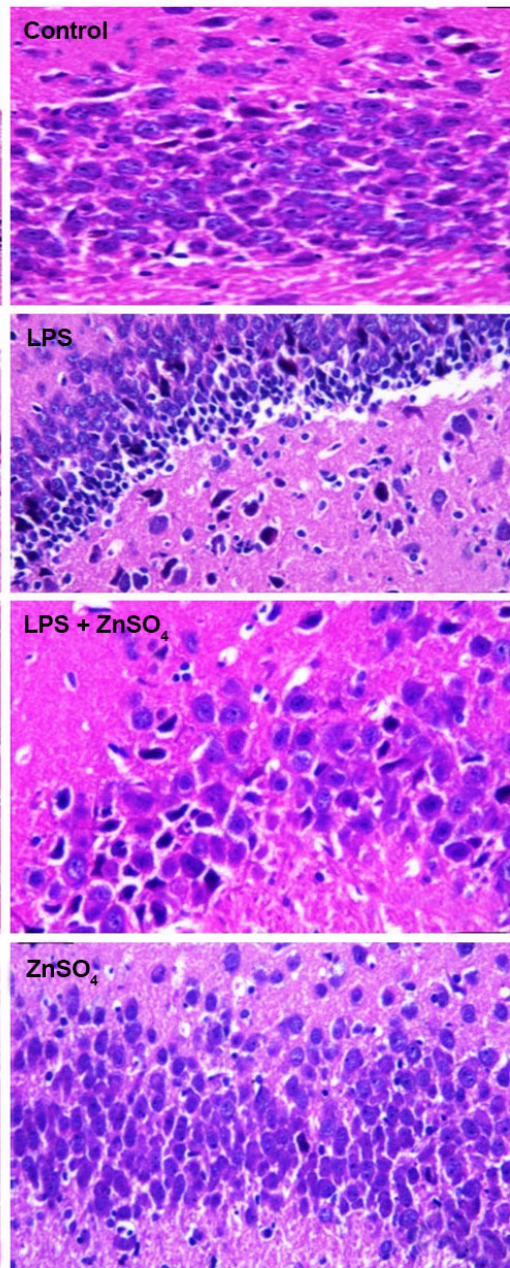

Figure 3: Representative figures are HE stained coronal sections of the brain showing the effect of prenatal zinc supplementation in hippocampal region of prenatally LPS treated $(A)$ male and $(B)$ female pups. Left side: $\times 10$; right side: $\times 40$. LPS: lipopolysaccharide

supplementation against LPS-induced endotoxemia during third trimester of pregnancy were investigated. It was observed that LPS-induced endotoxicity has major effects on female pups as compared to male pups. Although behavioral impairments were seen in both prenatally exposed male and female pups. Importantly prenatal zinc supplementation prevented these effects in female pups. Many studies have reported behavioral impairments in new born as well as adult off-spring due to early, mid or late gestational LPS exposure. According to Taweel et al., ${ }^{[49]}$ it was shown that gestational exposure of LPS has an inhibitory effect on righting reflex, rotating reflex and cliff avoidance activity in mice off-spring (PND21). Also, zinc supplementation during pregnancy significantly improved reduced motor activity and responsiveness in rats and monkeys. ${ }^{[50]}$ Similarly, in the present experiment with zinc supplementation to mothers throughout pregnancy showed improvement in total locomotor activity as well as rotarod behavior.
Prenatally LPS treated male and female pups spent maximum time in open arm on EPM and they escaped maximum number of trails in active avoidance test performed in the present study. This aberrant behavior can be due to loss of memory. Several reports demonstrated different memory based tests like nest-seeking, cliff avoidance and morris water maze etc. on prenatally LPS treated pups and pups showed impairment in behavior. ${ }^{[51,52]}$ Maternal zinc supplementation prevents aberrant behavior in object recognition task in mice off spring following early gestational exposure of LPS. ${ }^{[53]}$ In accordance with the previous reports in case of present study also an improvement in memory following maternal zinc supplementation was observed.

Loss of total locomotor activity and short term memory were further correlated with decrease in dopamine (DA) and serotonin (5-HT) levels. As per previous reports a long term reduction of DA and 5-HT along with other neurophysiological changes were observed 
due to early gestational exposure of LPS in rats. ${ }^{[54]}$ Also, a decrease in number of TH positive cells was observed in rat off-spring following LPS exposure. ${ }^{[55]}$ In the case of our study a significant decline in the levels of neurotransmitters DA, $5-\mathrm{HT}$ and NE were observed following LPS exposure which was further found to be improved in pups of zinc-supplemented mothers. This improvement in case of DA level was more significant in case of male pups as compared to female pups. This improvement in DA level in both sex pups could be related to the property that DA receptor regulating factor is a zinc finger transcription factor. ${ }^{[56]}$

A decrease in 5-HT levels in prenatally LPS exposed male and female pups could be related to decreased expression of serotonin transporter (5-HTT) was observed in somatosensory cortex using positron emission tomography in rabbit kits on post-natal day 1 when their mothers were injected with $20 \mu \mathrm{g} / \mathrm{kg}$ LPS intra-uterine on E28. ${ }^{[57]}$ On the contrary, significant augmentation in $5 \mathrm{HT}$ content was observed in frontal cortex of prenatally LPS $(1 \mathrm{mg} / \mathrm{mL}$ every second day from E7 until full-term) exposed female pups (PND21). Similarly, 5-HT levels were found to be significantly increased in co-supplemented group of both male and female pups in the current study. Also, studies have reported synergism of zinc and essential fatty acids in regulating $\mathrm{DA}, \mathrm{NE}$ and possibly serotonin activity as zinc is essential for conversion of dietary pyridoxine to its active form, pyridoxal phosphate, and pyridoxine is necessary for conversion of tryptophan to $5-\mathrm{HT}$. ${ }^{[58]}$

In the present study, a significant increase in levels of NE in pups of both genders from LPS treated mothers was observed. The results are supported by the report that LPS has direct effect on hypothalamus to stimulate the efflux of NE and this effect was probably due to $\mathrm{IL}-1 \beta{ }^{[59]} \mathrm{NE}$ negatively regulates the expression of pro-inflammatory cytokine expression at least to TNF- $\alpha$ which could contribute to the observed antiinflammatory properties of NE. ${ }^{[60]}$ However, NE levels were significantly decreased in co-supplemented pups. Further, the female pups from LPS treated mothers showed significant increase in NO levels and lipid peroxidation as depicted from increased MDA levels. However, in case of female pups from zinc supplemented mothers showed significant decrease in $\mathrm{NO}$ levels. It has been reported that $\mathrm{Zn}^{2+}$ inhibits

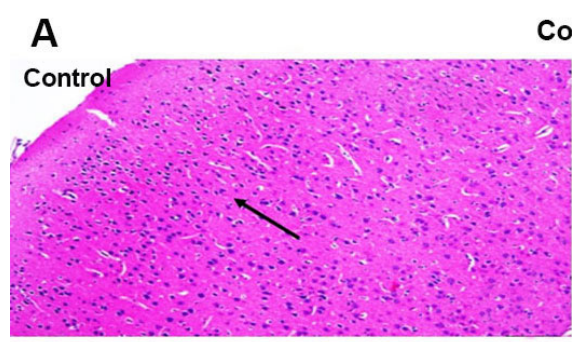

Cortex
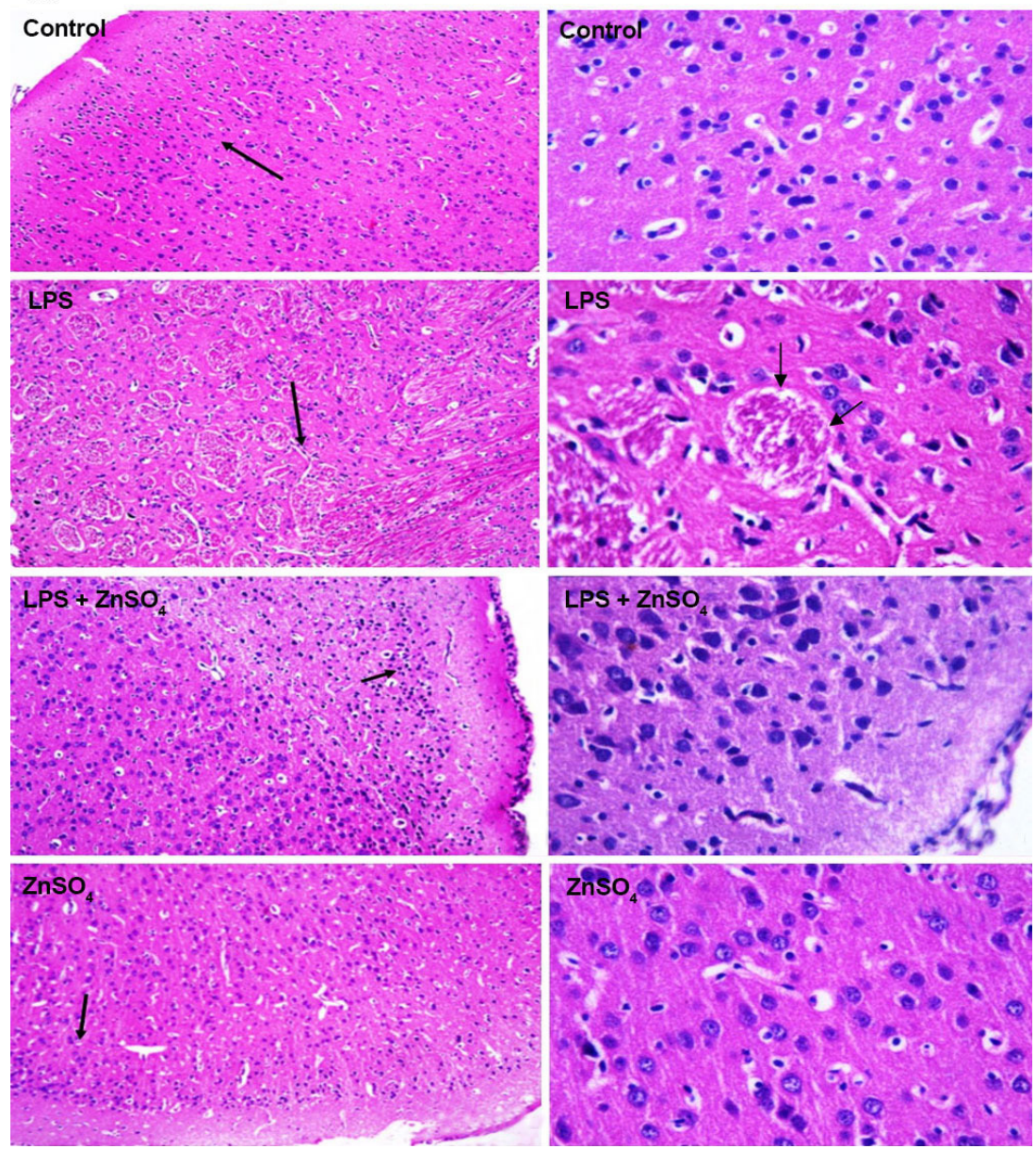


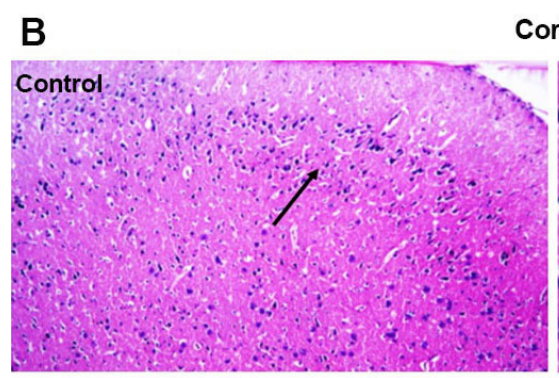

\section{Cortex}
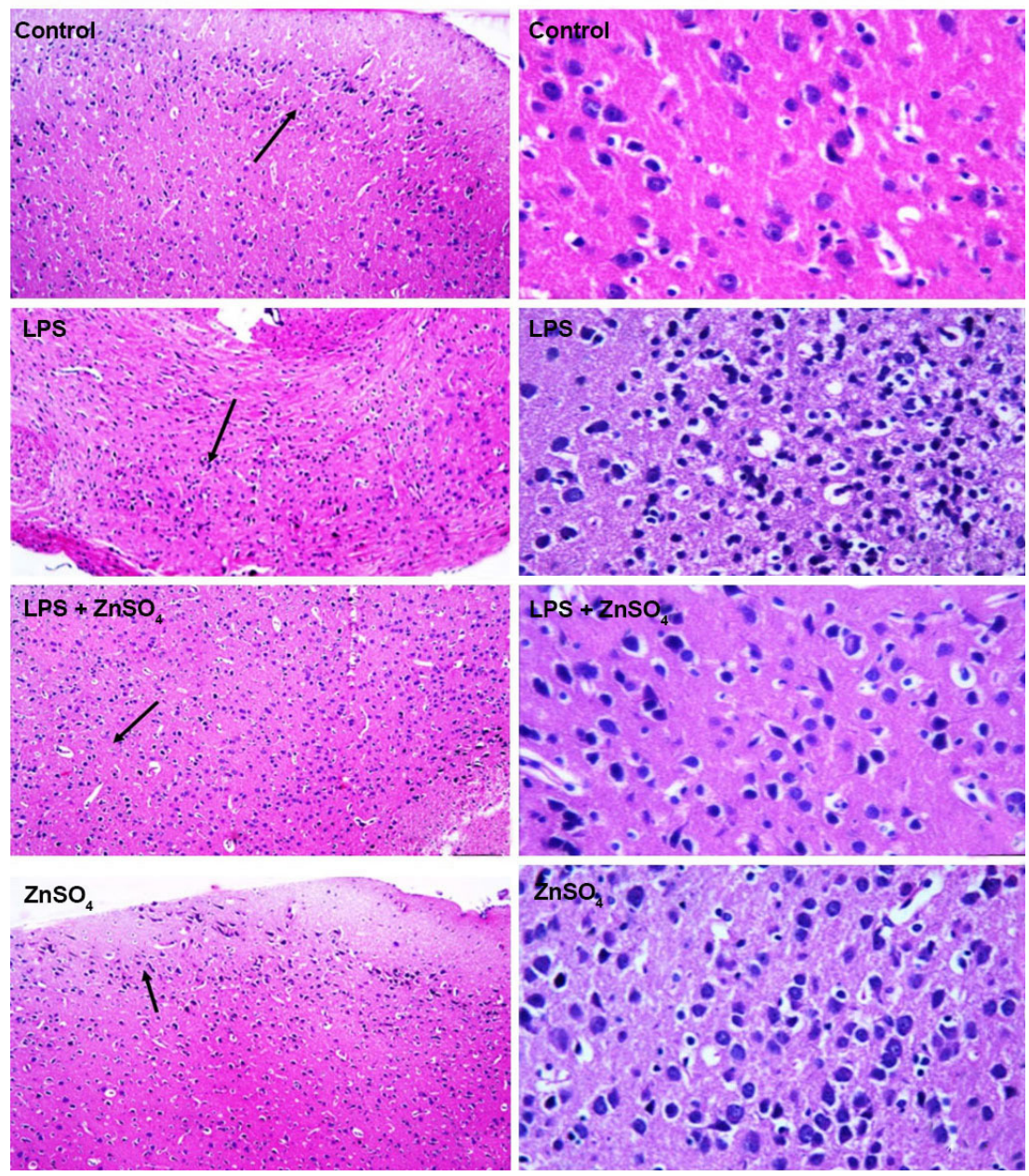

Figure 4: Representative figures are HE stained coronal sections of the brain showing the effect of prenatal zinc supplementation on cortex of prenatally LPS treated (A) male pups and (B) female pups. Left side: $\times 10$; right side: $\times 40$. LPS: lipopolysaccharide

production of inducible NO synthase to produce NO by (1) interfering with calcium-activated colmudulin function; (2) inhibiting NADPH dependent cytochrome P-450; and (3) by binding to glutathione and other thiols to decrease nitric oxide synthase activity. ${ }^{[1]}$

Significant reduction in GSH levels were observed in both prenatally LPS treated male and female pups. Whereas in case of pups from zinc supplemented mothers showed significantly increased GSH levels. Glutathione system is important for cellular defense against $\mathrm{ROS}$. $\mathrm{O}^{2-}$ and $\mathrm{NO}$ radicals, although they cannot react directly with $\mathrm{GSH}$, can oxidize $\mathrm{GSH}$ after undergoing intracellular redox reactions $\mathrm{NO}$ can react with $\mathrm{O}^{2-}$ by radical-radical interaction forming peroxynitrite (ONOO-), thus clearing and scavenging $\mathrm{O}^{2-}$ in a diffusion limited rate. ${ }^{[61-63]} \mathrm{ONOO}^{-}$is a strong oxidizing agent, a reactive nitrogen species which oxidizes GSH rapidly to GSSG and depletes intracellular store of GSH. Similar results for glutathione system have been previously reported as decrease in $\mathrm{GSH}$ levels of maternal and fetal liver at $3 \mathrm{~h}, 6 \mathrm{~h}$ and $16 \mathrm{~h}$ after LPS injection to pregnant mice was observed. ${ }^{[64]}$ Also, a significant decrease in levels of $\mathrm{GSH}$ in prenatally LPS treated mice pups and 4-month-old rats were reported. ${ }^{[65,66]}$ Studies showed therapeutic efficacy of $\mathrm{N}$-acetylcysteine, a potent anti-oxidant and precursor of glutathione to attenuate LPS-induced white matter injury and hypomyelination in the developing rat brain. ${ }^{[67]}$ Zinc was found to be effective in decreasing oxidative stress via metallothionein by regulating the secretion of pro-inflammatory cytokines ${ }^{[88]}$ and these metallothionein's are strong scavengers of free radicals. ${ }^{[69,70]}$ In the present study only prenatally LPS treated female pups showed significant decrease in the activity of catalase and SOD enzyme. However prenatal zinc supplementation was unable to restore the activity of both the enzymes.

Female pups were found to be more prone to ill effects of prenatal LPS exposure as compared to male pups. As suggested by Paris et al., ${ }^{[71]}$ more of anxiety 
levels in prenatally IL-1 $\beta$ exposed female pups were observed due to decrease in progesterone turnover to its metabolites in hippocampus which was not the same in case of male pups. However, this could also be related to differential increase of NE levels in case of pups of both sexes as observed in the present study. Results from histopathological studies were also in line with the above discussed results. Therefore, it can be suggested that LPS exposure prenatally effects pups and is gender specific and the same is the case with Zinc supplementation.

\section{Authors' contributions}

Study planning and experimental design: B. Nehru, N. Sharma

Experimental work and preparation of Tables and Figures: P. Arora, N. Sharma

Evaluation of the results: B. Nehru

Manuscript writing and communication: N. Sharma

\section{Financial support and sponsorship} None.

\section{Conflicts of interest}

There are no conflicts of interest.

\section{Patient consent \\ There is no patient involved.}

\section{Ethics approval}

Ethical approval was obtained prior to the commencement of the study.

\section{REFERENCES}

1. Jacob AI, Goldberg PK, Bloom N, Degenshein GA, Kozinn PJ. Endotoxin and bacteria in portal blood. Gastroenterology 1977;72:1268-70.

2. Genc S, Zadeoglulari Z, Fuss SH, Genc K. The adverse effects of air pollution on the nervous system. $J$ Toxicol 2012;2012:782462.

3. He Q, Yu W, Wu J, Chen C, Lou Z, Zhang Q, Zhao J, Wang J, Xiao B. Intranasal LPS-mediated Parkinson's model challenges the pathogenesis of nasal cavity and environmental toxins. PLoS One 2013;8:e78418.

4. Clapp WD, Thorne PS, Frees KL, Zhang X, Lux CR, Schwartz DA. The effects of inhalation of grain dust extract and endotoxin on upper and lower airways. Chest 1993;104:825-30.

5. Fukui H, Brauner B, Bode JC, Bode C. Plasma endotoxin concentrations in patients with alcoholic and non-alcoholic liver disease: reevaluation with an improved chromogenic assay. $J$ Hepatol 1991;12:162-9.

6. Zhou Z, Wang L, Song Z, Lambert JC, McClain CJ, Kang YJ. A critical involvement of oxidative stress in acute alcohol-induced hepatic TNF-alpha production. Am J Pathol 2003;163:1137-46.

7. Platz-Christensen JJ, Mattsby-Baltzer I, Thomsen P, Wiqvist N. Endotoxin and interleukin-1 alpha in the cervical mucus and vaginal fluid of pregnant women with bacterial vaginosis. Am J Obstet Gynecol 1993;169:1161-6.
8. Romero R, Roslansky P, Oyarzun E, Wan M, Emamian M, Novitsky TJ, Gould MJ, Hobbins JC. Labor and infection. II. Bacterial endotoxin in amniotic fluid and its relationship to the onset of preterm labor. Am J Obstet Gynecol 1988;158:1044-9.

9. Gendron RL, Nestel FP, Lapp WS, Baines MG. Lipopolysaccharideinduced fetal resorption in mice is associated with the intrauterine production of tumour necrosis factor-alpha. $J$ Reprod Fertil 1990;90:395-402.

10. Ogando DG, Paz D, Cella M, Franchi AM. The functional role of increased production of nitric oxide in lipopolysaccharide-induced embryonic resorption in mice. Reproduction 2003;125:95-110.

11. Leazer TM, Barbee B, Ebron-McCoy M, Henry-Sam GA, Rogers JM. Role of the maternal acute phase response and tumor necrosis factor alpha in the developmental toxicity of lipopolysaccharide in the CD-1 mouse. Reprod Toxicol 2002;16:173-9.

12. Zhao L, Chen YH, Wang H, Ji YL, Ning H, Wang SF, Zhang C, $\mathrm{Lu}$ JW, Duan ZH, Xu DX. Reactive oxygen species contribute to lipopolysaccharide-induced teratogenesis in mice. Toxicol Sci 2008;103:149-57.

13. Rivera DL, Olister SM, Liu X, Thompson JH, Zhang XJ, Pennline K, Azuero R, Clark DA, Miller MJ. Interleukin-10 attenuates experimental fetal growth restriction and demise. FASEB J 1998;12:189-97.

14. Buhimschi IA, Buhimschi CS, Weiner CP. Protective effect of Nacetylcysteine against fetal death and preterm labor induced by maternal inflammation. Am J Obstet Gynecol 2003;188:203-8.

15. Xu DX, Chen YH, Zhao L, Wang H, Wei W. Reactive oxygen species are involved in lipopolysaccharide-induced intra-uterine growth restriction and skeletal development retardation in mice. Am J Obstet Gynecol 2006;195:1707-14.

16. Xu DX, Wang H, Ning H, Zhao L, Chen YH. Maternally administered melatonin differentially regulates lipopolysaccharide-induced proinflammatory and anti-inflammatory cytokines in maternal serum, amniotic fluid, fetal liver, and fetal brain. J Pineal Res 2007;43:74-9.

17. Xu DX, Wang H, Zhao L, Ning H, Chen YH, Zhang C. Effects of lowdose lipopolysaccharide (LPS) pretreatment on LPS-induced intrauterine fetal death and preterm labor. Toxicology 2007;234:167-75.

18. Xu DX, Chen YH, Wang H, Zhao L, Wang JP, Wei W. Tumor necrosis factor alpha partially contributes to lipopolysaccharide-induced intrauterine fetal growth restriction and skeletal development retardation in mice. Toxicol Lett 2005:163:20-9.

19. Ning H, Wang H, Zhao L, Zhang C, Li XY, Chen YH, Xu DX. Maternally-administered lipopolysaccharide (LPS) increases tumor necrosis factor alpha in fetal liver and fetal brain: its suppression by low-dose LPS pretreatment. Toxicol Lett 2008;176:13-9.

20. Li XY, Zhang C, Wang H, Ji YL, Wang SF, Zhao L, Chen X, Xu DX Tumor necrosis factor alpha partially contributes to lipopolysaccharideinduced downregulation of CYP3A in fetal liver: its repression by a low dose LPS pretreatment. Toxicol Lett 2008;179:71-7.

21. Yoon BH, Jun JK, Romero R, Park KH, Gomes R, Choi JH, Kim IO Amniotic fluid inflammatory cytokines (interleukin-6, interleukin1 beta, and tumor necrosis factor-alpha), neonatal brain white matter lesions, and cerebral palsy. Am J Obstet Gynecol 1997;177:19-26.

22. Golan HM, Lev V, Hallak M, Sorokin Y, Huleihel M. Specific neurodevelopmental damage in mice offspring following maternal inflammation during pregnancy. Neuropharmacology 2005;48:903-17.

23. Golan H, Stilman M, Lev V, Huleihel M. Normal aging of offspring mice of mothers with induced inflammation during pregnancy. Neuroscience 2006;141:1909-18.

24. Hava G, Vered L, Yael M, Mordechai H, Mahoud H. Alterations in behavior in adult offspring mice following maternal inflammation during pregnancy. Dev Psychobiol 2006;48:162-8.

25. Roza SJ, van Batenburg-Eddes T, Steegers EA, Jaddoe VW, Mackenbach JP, Hofman A, Verhulst FC, Tiemeier H. Maternal 
folic acid supplement use in early pregnancy and child behavioural problems: The Generation R Study. Br J Nutr 2010;103:445-52.

26. Caulfield LE, Zavaleta N, Shankar AH, Merialdi M. Potential contribution of maternal zinc supplementation during pregnancy to maternal and child survival. Am J Clin Nutr 1998;68:S499-508.

27. Hirano T, Murakami M, Fukada T, Nishida K, Yamasaki S, Suzuki T. Roles of zinc and zinc signaling in immunity: zinc as an intracellular signaling molecule. Adv Immunol 2008;97:149-76.

28. Chen YH, Zhao M, Chen X, Zhang Y, Wang H, Huang YY, Wang Z, Zhang ZH, Zhang C, Xu DX. Zinc supplementation during pregnancy protects against lipopolysaccharide-induced fetal growth restriction and demise through its anti-inflammatory effect. J Immunol 2012;189:454-63.

29. Rink L, Haase H. Zinc homeostasis and immunity. Trends Immunol 2007;28:1-4.

30. Haase H, Rink L. Functional significance of zinc-related signaling pathways in immune cells. Annu Rev Nutr 2009;29:133-52.

31. Abou-Mohamed G, Papapetropoulos A, Catravas JD, Caldwell RW. $\mathrm{Zn}^{2+}$ inhibits nitric oxide formation in response to lipopolysaccharides: implication in its anti-inflammatory activity. Eur $J$ Pharmacol 1998;341:265-72.

32. Zhou Z, Wang L, Song Z, Saari JT, McClain CJ, Kang YJ. Abrogation of nuclear factor- $\kappa \mathrm{B}$ activation is involved in zinc inhibition of lipopolysaccharide-induced tumor necrosis factor- $\alpha$ production and liver injury. Am J Pathol 2004;164:1547-56.

33. von Bülow V, Rink L, Haase H. Zinc-mediated inhibition of cyclic nucleotide phosphodiesterase activity and expression suppresses TNFalpha and IL-1 beta production in monocytes by elevation of guanosine 3',5'-cyclic monophosphate. J Immunol 2005;175:4697-705.

34. von Bülow V, Dubben S, Engelhardt G, Hebel S, Plümäkers B, Heine H, Rink L, Haase H. Zinc-dependent suppression of TNF-alpha production is mediated by protein kinase A-induced inhibition of Raf-1, I kappa B kinase beta, and NF-kappa B. J Immunol 2007;179:4180-6.

35. Takeda A, Itoh H, Yamada K, Tamano H, Oku N. Enhancement of hippocampal mossy fiber activity in zinc deficiency and its influence on behavior. Biometals 2008;21:545-52.

36. Tassabehji NM, Corniola RS, Alshingiti A, Levenson CW. Zinc deficiency induces depression-like symptoms in adult rats. Physiol Behav 2008;95:365-9.

37. Paoletti P, Vergnano AM, Barbour B, Casado M. Zinc at glutamatergic synapses. Neuroscience 2009;158:126-36.

38. Ochiogu IS, Uchendu CN, Ihedioha JI. A new and simple method of confirmatory detection of mating in Albino Rats (Rattus norvegicus). Anim Res Int 2006;3:527-30.

39. Pellow S, Chopin P, File SE, Briley M. Validation of open: closed arm entries in an elevated plus-maze as a measure of anxiety in the rat. $J$ Neurosci Methods 1985;14:149-67.

40. Miyamoto M, Shintani M, Nagaoka A, Nagawa Y. Lesioning of the rat basal forebrain leads to memory impairments in passive and active avoidance tasks. Brain Res 1985;328:97-104.

41. Kulkarni SK. Handbook of Experimental Pharmacology. 3rd edition. Delhi: Vallabh Prakashan; 1999. p. 117-21.

42. Dunham NW, Miya TS. A note on a simple apparatus for detecting neurological deficit in rats and mice. J Am Pharm Assoc Am Pharm Assoc 1957;46:208-9.

43. Church WH. Column chromatography analysis of brain tissue: an advanced laboratory exercise for neuroscience majors. $J$ Undergrad Neurosci Educ 2005;3:A36-41.

44. Raddassi K, Berthon B, Petit JF, Lemaire G. Role of calcium in the activation of mouse peritoneal macrophages: induction of $\mathrm{NO}$ synthase by calcium ionophores and thapsigargin. Cell Immunol 1994; 153:443-55.

45. Wills ED. Mechanism of lipid peroxide formation in animal tissues.
Biochem J 1966;99:667-76.

46. Luck H. Catalase In: Methods of Enzymatic Analysis, Bergmeyer, H.U. (Ed.). New York: Academic Press; 1971. p. 855.

47. Kono Y. Generation of superoxide radical during autoxidation of hydroxylamine and assay for superoxide dismutase. Arch Biochem Biophys 1978;186:189-95.

48. Humason GL. Animal tissue techniques. San Francisco: W.H Freeman; 1967. p. 351-2.

49. Taweel GA, Ajarem JS, Ebaid H, Rady AM. Behavioral changes induced by prenatal acute endotoxemia in mice offspring. Pakistan $J$ Zool 2013;45:359-69.

50. Golub MS, Keen CL, Gershwin ME, Hendrickx AG. Developmental zinc deficiency and behavior. J Nutr 1995;125:S2263-71.

51. Baharnoori M, Bhardwaj SK, Srivastava LK. Neonatal behaviora changes in rats with gestational exposure to lipopolysaccharide: a prenatal infection model for developmental neuropsychiatric disorders. Schizophr Bull 2012;38:444-56.

52. Chlodzinska N, Gajerska M, Bartkowska K, Turlejski K, Djavadian RL. Lipopolysaccharide injected to pregnant mice affects behavior of their offspring in adulthood. Acta Neurobiol Exp (Wars) 2011;71:519-27.

53. Coyle P, Tran N, Fung JN, Summers BL, Rofe AM. Maternal dietary zinc supplementation prevents aberrant behaviour in an object recognition task in mice offspring exposed to LPS in early pregnancy. Behav Brain Res 2009;197:210-8.

54. Ling Z, Gayle DA, Ma SY, Lipton JW, Tong CW, Hong JS, Carvey PM. In utero bacterial endotoxin exposure causes loss of tyrosine hydroxylase neurons in the postnatal rat midbrain. Mov Disord 2002; 17:116-24

55. Lin YL, Lin SY, Wang S. Prenatal lipopolysaccharide exposure increases anxiety-like behaviors and enhances stress-induced corticosterone responses in adult rats. Brain Behav Immun 2012;26:459-68.

56. Hwang CK, D’Souza UM, Eisch AJ, Yajima S, Lammers CH, Yang Y, Lee SH, Kim YM, Nestler EJ, Mouradian MM. Dopamine receptor regulating factor, DRRF: a zinc finger transcription factor. Proc Natl Acad Sci U S A 2001;98:7558-63.

57. Kannan S, Saadani-Makki F, Balakrishnan B, Dai H, Chakraborty PK, Janisse J, Muzik O, Romero R, Chugani DC. Decreased cortical serotonin in neonatal rabbits exposed to endotoxin in utero. $J$ Cereb Blood Flow Metab 2011;31:738-49.

58. Bilici M, Yildirim F, Kandil S, Bekaroğlu M, Yildirmiş S, Değer O, Ulgen M, Yildiran A, Aksu H. Double-blind, placebo-controlled study of zinc sulfate in the treatment of attention deficit hyperactivity disorder. Prog Neuropsychopharmacol Biol Psychiatry 2004;28:181-90.

59. Francis J, MohanKumar PS, MohanKumar SM. Lipopolysaccharide stimulates norepinephrine efflux from the rat hypothalamus in vitro: blockade by soluble IL-1 receptor. Neurosci Lett 2001;308:71-4.

60. Kaneko YS, Mori K, Nakashima A, Sawada M, Nagatsu I, Ota A. Peripheral injection of lipopolysaccharide enhances expression of inflammatory cytokines in murine locus coeruleus: possible role of increased norepinephrine turnover. J Neurochemistry 2005;94:393-404.

61. Wink DA, Cook JA, Krishna MC, Hanbauer I, DeGraff W, Gamson J, Mitschell JB. Nitric oxide protects against alkyl peroxide mediated cytotoxicity: further insights into the role nitric oxide plays in oxidative stress. Arch Biochem Biophys 1995;319:402-7.

62. Gupta MP, Evanoff V, Hart CM. Nitric oxide attenuates hydrogen peroxide-mediated injury to porcine pulmonary artery endothelial cells. Am J Physiol 1997;272:L1133-41.

63. Wink DA, Mitschell JB. Chemical biology of nitric oxide: insights into regulatory, cytotoxic, and cytoprotective mechanisms of nitric oxide. Free Radic Biol Med 1998;25:434-56.

64. Buhimschi IA, Buhimschi CS, Weiner CP. Protective effect of $\mathrm{N}$-acetylcysteine against fetal death and preterm labor induced by 
maternal inflammation. Am J Obstet Gynecol 2003;188:203-8.

65. Ebaid H, Ajarem J, Taweel GA. Acute endotoxemia during gestation induces organ dysfunction and tissue damage in mouse offspring. Pakistan J Zool 2012;44:765-76.

66. Tomasi ML, Ryoo M, Yang H, Ara AI, Ko KS, Lu SC. Molecular mechanisms of lipopolysaccharide-mediated inhibition of glutathione synthesis in mice. Free Radic Biol Med 2014:68:148-58.

67. Paintlia MK, Paintlia AS, Barbosa E, Singh I, Singh AK $\mathrm{N}$-acetylcysteine prevents endotoxin-induced degeneration of oligodendrocyte progenitors and hypomyelination in developing rat brain. J Neurosci Res 2004;78:347-61.

68. Prasad AS. Zinc: role in immunity, oxidative stress and chronic inflammation. Curr Opin Clin Nutr Metab Care 2009;12:646-52.

69. Thornalley PJ, Vasak M. Possible role for metallothionein in protection against radiation-induced oxidative stress. Kinetics and mechanism of its reaction with superoxide and hydroxyl radicals. Biochim Biophys Acta 1985;827:36-44.

70. Greenstock CL, Jinot CP, Whitehouse RP, Sargent MD. DNA radiation damage and its modification by metallothionein. Free Radic Res Commun 1987;2:233-9.

71. Paris JJ, Brunton PJ, Russell JA, Frye CA. Frye immune stress in late pregnant rats decreases length of gestation and fecundity, and alters later cognitive and affective behaviour of surviving pre-adolescent offspring. Stress 2011;14:652-64. 